\title{
International migration of unaccompanied minors: trends, health risks, and legal protection
}

Susanna Corona Maioli, Jacqueline Bhabha, Kolitha Wickramage, Laura C N Wood, Ludivine Erragne, Omar Ortega García, Rochelle Burgess, Vasileia Digidiki, Robert Aldridge, Delan Devakumar

The global population of unaccompanied minors-children and adolescents younger than 18 years who migrate without their legal guardians-is increasing. However, as data are not systematically collected in any region, if collected at all, little is known about this diverse group of young people. Compared with adult migrants, unaccompanied minors are at greater risk of harm to their health and integrity because they do not have the protection provided by a family, which can affect their short-term and long-term health. This Review summarises evidence regarding the international migration and health of unaccompanied minors. Unaccompanied minors are entitled to protection that should follow their best interests as a primary consideration; however, detention, sometimes under the guise of protection, is a widespread practice. If these minors are provided with appropriate forms of protection, including health and psychosocial care, they can thrive and have good long-term outcomes. Instead, hostile immigration practices persist, which are not in the best interests of the child.

\section{Introduction}

The UN Convention on the Rights of the Child (CRC) defines an unaccompanied minor as a child or adolescent younger than 18 years who is "separated from both parents and other relatives and is not being cared for by any other adult who, by law or custom, is responsible for doing so". ${ }^{1}$ Children who are accompanied by adult caregivers (who are not parents) are defined as separated children and form a distinct legal category. As many of these children and adolescents escape from deprivation, isolation, and neglect, migration can be a viable and lifesaving strategy if it leads to opportunities that allow them to thrive. ${ }^{2}$ However, as travel routes become restrictive, migration can threaten the physical and emotional integrity of unaccompanied minors, especially if they are girls, have disabilities, or identify as lesbian, gay, bisexual, transgender, queer, or questioning (plus; LGBTQ+). Border enforcement with few and lengthy legal pathways to migrate results in unaccompanied minors relying on smugglers for their journey or migrating alone, which risks highly unsafe travel and increases their vulnerability to human trafficking. ${ }^{3-6}$ The credibility of many unaccompanied minors' asylum claims is questioned without adequate legal assistance and they are threatened with deportation once they turn 18 years old..$^{-9}$ These challenges result in overburdened and unsuitable child protection systems that lead to missing or untraced minors (panel 1)..$^{10}$ The COVID-19 pandemic has made these pushbacks from governments worse. ${ }^{11,12}$ For example, the public health emergency has been used by the Hungarian Government to justify the closure of asylum procedures ${ }^{13}$ and the US Customs and Border Patrol has reportedly increased deportion of unaccompanied minors despite credible asylum claims [A: edit ok?]. ${ }^{11}$ Additionally, services to support unaccompanied minors are inadequate despite the advocacy of existing recommendations, ${ }^{14}$ leading to increasingly complex and challenging risks to child health, as exemplified by situations of indefinite containment in the Greek islands of the Aegean Sea..$^{15}$ In this Review, we summarise demographic trends in international migration of unaccompanied minors and the risks they face, and provide a contextualised and evidence-based summary of their physical and mental health outcomes. We address the laws and policies that can be implemented to reduce harm to unaccompanied minors, discuss the implications of these findings, and provide recommendations to protect the rights of these children and adolescents.

\section{Demographic trends}

To acknowledge a problem, it is important to document

\section{Key messages}

- Unaccompanied minors are a group of migrants younger than 18 years who travel without legal guardians; they are exposed to migration-related risks leading to poor health

- There is a scarcity of comprehensive data on unaccompanied minors, especially for those who are girls, have disabilities, or are lesbian, gay, bisexual, transgender, queer, or questioning (plus; LGBTQ+), partly resulting from difficulties in identifying these groups and increased irregular migration due to border closures

- Health challenges for unaccompanied minors include nutritional deficiencies, dental caries, skin and gastrointestinal infections, low vaccination coverage, post-traumatic stress disorder, depression, and anxiety

- Protective childhood experiences-such as belonging, appropriate accommodation, and health and educational schemes-are fundamental in reverting adverse health consequences in the long term

- Child health professionals have a valuable role in advocating for better health for unaccompanied minors and in using an evidence-based approach in their clinical care
Lancet Child Adolesc Health 2021 Institute for Global Health (S Corona Maioli MBBS, R Burgess PhD), Institute of Health Informatics (R Aldridge PhD), and Institute for Global Health (D Devakumar PhD), UCL, London, UK; Harvard FXB Center for Health and Human Rights, Harvard University, Boston, MA, USA (Prof) Bhabha JD, V Digidiki PhD); Migration Health Division, Global Migration Health Research and Epidemiology Unit, International Organization for Migration, Manila, Philippines (K Wickramage PhD); Centre for Child \& Family Justice Research, Lancaster University, Lancaster, UK (LCN Wood MRCPCH); Médecins Sans Frontières, Paris, France (L Erragne JD); Programa Casa Refugiados Asociación Civil, Mexico City, Mexico (O Ortega García BSc)

Correspondence to: Dr Susanna Corona Maioli, Institute for Global Health, UCL, London WC1N 1EH, UK susanna.corona.19@ucl.ac.uk 
Panel 1: Case studies

\section{Paris, France}

Since 2017, Médecins Sans Frontières (MSF; Paris, France) has provided medical, psychological, legal, and social assistance to more than 1700 unaccompanied minors in France. $X$ is one of these unaccompanied minors from Côte d'Ivoire and he has been in France since 2018. During his migration, he suffered sexual violence in Libya and became infected with HIV. As the protocol of care in France was likely to be compromised by the absence of a legal representative, $X$ appealed to the juvenile judge in Nanterre, who temporarily placed him under the protection of child protection services (Aide Sociale à l'Enfance) of the Hauts-deSeine department and requested a bone examination to confirm his alleged minority status. Since the assessment did not show minor age, the Juvenile Judge ordered the release of the provisional placement measure. Housed by MSF during confinement (March, 2020, to May, 2020), he contracted COVID-19 and his clinical condition deteriorated. Admitted to a hospital in the department of Seine-Saint-Denis, he requested the reopening of his file before the Juvenile Court Judge of Nanterre. The Juvenile Judge refused to reopen the case. The hospital then forwarded a notification of the worrying situation to the Departmental Council of Seine-Saint-Denis, which ignored the request since $X$ had originally been evaluated in another department. The exhaustion of traditional means of recourse and X's medical situation led MSF to file a complaint on July 1, 2020, against the Departmental Council of Seine-Saint-Denis on the grounds of abandonment of a person who is unable to protect himself, endangerment of the life of a person, and failure to assist a person in danger due to no follow-up. The complaint is awaiting a decision from the Public Prosecutor of the Republic. This case reveals the dysfunction of the child protection services and the neglect of minors even when they are vulnerable.

\section{Mexico City, Mexico}

In Mexico, few spaces exist that specifically care for unaccompanied minors as alternatives to detention. Casa de Acogida Formación y Empoderamiento de la Mujer Migrante y Refugiada (CAFEMIN), a migrant shelter in Mexico City, is one of them, where different strategies have been developed to guarantee access to basic services and protection to the best interests of the child. Before the COVID-19 pandemic, CAFEMIN received an average of 15-20 unaccompanied minors a month, who stayed 1-3 months in case of so-called voluntary returns and up to a year for those seeking regularisation (ie, legal status or family reunification) in Mexico. Every unaccompanied minor in Mexico has legal representation by the child protection authority for their regularisation while their care is under the responsibility of the national child welfare (Desarrollo Integral de la Familia). However, uncertainty and long waiting times mean that these minors often decide to escape the shelters and continue their journey north or back home, giving up their asylum-seeking process in Mexico. Access to mental health services is one of the key aspects of care for unaccompanied minors and CAFEMIN works with psychiatry and psychology teams. Access to health services is more probable when the minor is accompanied by CAFEMIN staff. For example, the complex case of a girl aged 17 years from Honduras who had a psychotic crisis and had to be admitted to hospital, and a boy aged 11 years from El Salvador who broke his arm and needed surgery and later rehabilitation. Although reception and care for unaccompanied minors in Mexico needs to be strengthened, the presence of appropriate legislation and the efforts of civil society spaces, such as CAFEMIN, are steps towards a better future for every child. it and collect adequate data to inform policy or advocacy. Data collection and documentation are the first challenges regarding unaccompanied minors and their health. Recorded trends in the global migration of unaccompanied minors are mostly based on asylum applications filed by these minors. Relying on asylum applications means that not only are data likely to be large underestimates, but hidden populations (eg, those who are undocumented or in transit) and subpopulations (eg, girls, people who are LGBTQ+, people with disabilities) are also mostly invisible due to being less likely to file for asylum than other refugees or because of absence of data granularity [A: edit ok?]. Collecting data on unaccompanied minors is complicated by the avoidance of detection that characterises irregular migration and the difficulty in identifying migrants younger than 18 years, given the common absence of identity documents and the inaccuracy of age assessment procedures. ${ }^{16}$ However, 5 even when identified, varying definitions of unaccompanied minors hinder comparability between regions, ${ }^{17}$ and estimates are often based on stock data (ie, the number at one point) rather than flow data (ie, the changes over time), with flow data being more useful for policy making and monitoring than stock data. The scarcity of data is not only due to practical difficulties. There is a clear correlation between accurate data collection, government accountability, and public perception of migration, especially regarding data of child migrants and of the deaths of migrants. ${ }^{17,19}$

Although there is no good data on unaccompanied 
minors, it is still important to provide a quantitative and geographical framework of migration of unaccompanied minors and its implications (eg, child labour, trafficking, and asylum claims). The global number of child migrants has increased from 24 million in 2000 to 33 million in $2019,{ }^{20}$ but after accounting for population growth, the proportion of child migrants as a percentage of the global population has remained constant at $0 \cdot 4 \% .{ }^{21}$ In 2019 , the number of children internally displaced, mainly in lowincome and middle-income countries such as Brazil, China, and Indonesia, ${ }^{22,23}$ was 19 million (for whom agedisaggregated data are available; 13 million were refugees). ${ }^{24,25}$ Regarding unaccompanied minors, according to the latest data available from UNICEF and UN High Commissioner for Refugees (UNHCR), 300000 child migrants were reported to be unaccompanied or separated in $2015-16,{ }^{3,26}$ and 153300 unaccompanied minors were reported among the refugee population in 2019..$^{25}$ Due to border closures during the COVID-19 pandemic, the number of unaccompanied minors has probably increased. ${ }^{27-29}$

There is a need for global estimates of child labour among child migrants and unaccompanied minors. ${ }^{30,31}$ There are documented links between migration, child labour, and trafficking. ${ }^{22,32,33}$ In 2016, 152 million children 2 aged 5-17 years were working, of whom $48 \%$ (73 million) were working in hazardous labour (eg, commercial sexual exploitation, illicit activities, forced labour, underground mining, or spraying pesticides). ${ }^{34}$ Children in need are at increased risk of being trafficked. 3 According to the 2018 UN Office on Drugs and Crime's Global Report on Trafficking in Persons, ${ }^{35} 30 \%$ of all human trafficking victims globally are minors, $77 \%$ of whom are girls. There are no estimates of the specific forms of trafficking to which child migrants and unaccompanied minors are most exposed..$^{0,31}$

Six main migration corridors situate migration of unaccompanied minors geographically: the central Mediterranean route from north Africa to Italy through Libya; ${ }^{3}$ the Balkan route from Afghanistan, Syria, and Iran to Serbia and Greece through Turkey; ${ }^{6}$ from central America to the USA through Mexico; ${ }^{3}$ internal and across border displacement in the horn of Africa; ${ }^{3,36}$ internal and across border labour migration in southeast Asia; ${ }^{37,38}$ and from Afghanistan, Bangladesh, and Myanmar to Australia through Malaysia, Thailand, and Indonesia. ${ }^{39,40}$ The routes to Europe and North America are the routes with the most data availability, specifically for data on asylum claims or apprehensions. ${ }^{3}$ For example, in the $27 \mathrm{EU}$ countries and the UK, unaccompanied minors filed 17110 asylum applications in $2019,{ }^{41}$ mostly in the UK (3651 applications), ${ }^{42}$ Greece (3300), ${ }^{x \times 1}$ Germany (2700), ${ }^{\times \times 2}$ and Belgium (1200). ${ }^{43, \times 3}$ This number of applications is part of a decreasing trend from a peak of 95205 applications in 2015, partly due to the EU-Turkey agreement on the closure of the Balkan route in March, 2016, and the Italy-Libya Memorandum of Understanding in
February, 2017.44,45 However, these decreased numbers reflect asylum claims, rather than border crossings or detentions. Unaccompanied minors continue undetected to be smuggled or trafficked, or else are deported, sometimes violently, even if they express the desire to claim asylum. ${ }^{6}$ Border closure is a sadly repeated policy in the central America-Mexico-USA route, with the militarisation of the Mexican and Guatemalan borders negotiated by both the Trump and Biden administrations. ${ }^{46,47}$ The ongoing increase in unaccompanied minors in the central America-Mexico-USA route is similar to the southwest border peak [A: please could you clarify the "southwest border", this has not been mentioned before] of 76020 unaccompanied minors apprehended in the fiscal year of 2019.48,49

Gender-based differences in child migration are important, although little is known about them. Studies from African countries report that girls are more likely to migrate internally in that region [A: to other African countries or within the country?] than boys, ${ }^{50,51}$ whereas unaccompanied minors in international migration are mostly boys aged $15-17$ years. ${ }^{16,52}$ Of concern, data on the migration patterns of children who identify as LGBTQ+ are absent.

Based on global asylum applications, unaccompanied minors are most often from Afghanistan and Eritrea; ${ }^{25}$ for the central America-Mexico-USA route, they are most often from Honduras, Guatemala, and El Salvador (for which only border patrol apprehension data are available). ${ }^{48}$ As of 2019, most unaccompanied child refugees were in Ethiopia (41500), Uganda (40000), Kenya (10700), and Cameroon (9000). ${ }^{25}$

In summary, despite a scarcity of comprehensive data, it is clear that the migration of unaccompanied minors is a global event and this group is not a homogeneous population.

\section{Risk factors}

Unaccompanied minors face many additional health risks compared with adult migrants and the risk differentially affects different ages, genders, abilities, and geographical contexts. Unaccompanied minors are more suspectable to migration risks than adults and have different consequences. The sensitive physical, mental, and psychological developmental stages of childhood and adolescence enhance the risks of disease and trauma, which are increased by isolation from a protective family unit. ${ }^{53}$ While unaccompanied minors engage in survival, they are missing the time needed to develop their full potential through educational or vocational opportunities. The pre-existing life experiences and health status add to the diversity of health effects on unaccompanied minors.

\section{Home country}

The risks that minors encounter in their home countries include poverty, extreme weather events, hunger, unhealthy living conditions, inadequate health and 
education services, military or gang recruitment, direct 1 or witnessed conflict, and violence and abuse. ${ }^{53-56}$ These risks are often not exclusive of each other and are exacerbated for children who become separated from their family in the home country or who have a family history of neglect and deprivation. Situations of poverty and hunger can lead to conflict and scarcity of services (or vice versa). The number of countries in conflict is at its highest point since 1990, with protracted conflicts in Syria, Yemen, and the Central African Republic..5 1 Violence in other areas can cause the same devastating effects as those in conflict areas. Gang violence in central America and terrorist incursions in west and central African countries lead to disrupted education, abuse, and death at unsustainable levels. ${ }^{57}$ All these risks are 1 exacerbated by natural disasters. ${ }^{55}$ For example, the COVID-19 pandemic has substantially exacerbated cases of intimate partner violence, gender-based violence, and domestic abuse. ${ }^{58}$ Although not all unaccompanied minors have disrupted family structures, many experience, or witness, violence in their families, ${ }^{59-61}$ which can lead to neglect or abuse. Despite the important risks of migration, it is sometimes riskier to stay, affecting those less able to migrate due to disability, illness, or scarcity of resources. ${ }^{62}$

\section{Transit}

Migration transit has become increasingly risky as unaccompanied minors are faced with border closures, ${ }^{3,57}$ leading to increased smuggling and risk along the migration route or prolonged confinement in dangerous transit countries or conflict areas. ${ }^{44,63}$ Complex and long legal routes to rejoin family or receive asylum can make the option of being smuggled paradoxically easier than migrating legally. ${ }^{3,56}$ Despite irregular migration journeys being longer (sometimes months or years ${ }^{56}$ ) and riskier than legal migration journeys, profit-driven smuggling services to reach or move within the EU generated €4.5-5.7 billion in 2015. ${ }^{3}$ Children can be exposed to deprivation, exploitation, extortion, abuse, 4 and death during such journeys. ${ }^{64-66}$ The Missing Migrants Project of the International Organization for Migration keeps a record of deaths of migrants in transit, from either body remains or survivor reports. Although not disaggregated by accompaniment status, from 2014 to 2018, the Missing Migrants Project recorded 678 child deaths by drowning in the Mediterranean, 40 while travelling by foot or land transport to Europe, 337 while migrating in Africa, 363 in southeast Asia, and 84 along the central America-Mexico-USA route. ${ }^{67}$ Due to 50 detection avoidance, fear of reporting, and environmental degradation of body remains, many deaths are unidentified. ${ }^{17}$ Many minors try to stay undetected; being exposed means losing independence, thus failing to meet responsibilities and expectations of their family. ${ }^{54}$

Unaccompanied minors are also at increased risk of being trafficked, often through deception, coercion, and force. Although smuggling is a crime against the state, trafficking is a crime of severe human rights violation, with children relocated or harboured for sexual, labour, or criminal exploitation. ${ }^{6}$ The risk of sexual abuse in transit is particularly high for girls..$^{56,66}$

\section{Destination}

In destination countries, there is often tension between border enforcement (which criminalises irregular migration) and a child rights-based assessment of health needs. ${ }^{56}$ Reports of physical, verbal, and sexual abuse from border enforcement officials ${ }^{3,66,68}$ are coupled with detention conditions that explicitly violate human rights. ${ }^{56,68}$ Prolonged detention is justified on the grounds of unavailable child welfare spaces, flight risk (ie, leaving the country before a trial hearing), or age determination disputes, with conditions such as sleep deprivation, inadequate food or water, and denied medical care being common. ${ }^{69}$ Interviews with asylum officers can be frightening and confusing (eg, there might be language barriers or no access to translators), and children might not be recognised as minors unless they have age confirmation..$^{70,71}$ Minors might hide their age because they want to continue the journey unhindered, as an 25 agreed or threatened component of the smuggling arrangement or trafficking situation, or to hide their vulnerability. ${ }^{6}$ Additionally, due to long waiting times to obtain an immigration status and the cessation of their rights as children when they reach their 18th birthday, ${ }^{4}$ many unaccompanied minors are left undocumented or in a state of legal limbo and disempowerment. ${ }^{71}$ It is difficult, if not impossible, to build a future under constant deportation threat, as deportation carries the risk of returning to dangerous situations with feelings of failure and peer discrimination. ${ }^{72}$ This rights chasm results in a high number of disappearances, ${ }^{3}$ often into trafficking. For example, in Italy and Greece alone, a 2020 European Migration Network report stated that 8229 unaccompanied minors went missing in 2018 and $2019 .^{73}$

Unaccompanied minors are also exposed to discrimination, particularly if they are from minoritised groups. $^{7476}$ Media coverage that oversimplifies and dehumanises migration and promotes public views of migrants as a national threat is garnering support for border enforcement measures. ${ }^{69}$ Although the risk of substance use among unaccompanied minors has not been vastly studied, it has been acknowledged, especially among those who are refugees or seeking asylum. ${ }^{779}$ Many situations these minors find themselves in on arrival of their destination predispose them to community, gender-based, or sexual violence, including in reception facilities. ${ }^{80,85}$ Without access to a safe environment and with chronic uncertainty about the future, substance use becomes a coping mechanism, $, 7,79,86$ and can be used to control children in a trafficking context. $^{87}$ 


\section{Health}

Unaccompanied minors are entitled to the "highest attainable standard of health" and to "non-discrimination" under the UN CRC. ${ }^{1}$ As such, the health of unaccompanied minors should be considered in the wider frame of child and adolescent health and its effect on long-term and intergenerational health. ${ }^{88}$ An umbrella review, consisting of eight systematic and narrative reviews, of the health literature on unaccompanied minors can be found in the table: ${ }^{89-96}$ additional original research articles are included in the appendix pp 1-4 [A: please provide appendix page range. We require appendices to be in one document with page numbers. Please also take note that we do not edit appendices, so please provide it how you wish it to be published]).

\section{Physical health and development}

The most prevalent physical conditions reported for unaccompanied minors are nutritional deficiencies; intestinal, respiratory, and skin infections; low vaccination coverage; and physical trauma due to violence or harsh migration transit. Due to an unstable lifestyle and unhygienic living circumstances, dental caries has been described among unaccompanied minors, with prevalence as high as $65 \%,{ }^{11}$ which makes it important to include a dental examination during a medical review of unaccompanied minors. ${ }^{99-101}$ In a meta-analysis by Baauw and colleagues, ${ }^{90}$ vitamin $\mathrm{D}$ deficiency was reported to affect $45 \%$ of refugee children from Africa, Asia, and the Middle East, and, in a review of undocumented children in Europe, iron-deficiency anaemia prevalence ranged from $4 \%$ to $18 \% .^{91}$ Although situations of conflict and displacement expose unaccompanied minors to the risk of undernutrition, more stable, but still uncertain, living conditions predispose children to malnourishment due to an unhealthy lifestyle and $\operatorname{diet}^{89}$ and increase risk factors for non-communicable diseases ${ }^{102}$ Communicable disease prevalence is related to conditions during and after migration..$^{91}$ Baauw and colleagues ${ }^{90}$ reported a prevalence of $31 \%$ for intestinal infections and $11 \%$ for latent tuberculosis in children who are refugees children. Similarly, other studies have reported that $44 \%$ of 226 unaccompanied minors in Geneva had parasitosis, ${ }^{103}$ and, in two UK clinics, 23\% of 238 unaccompanied minors had a tuberculosis infection and $16 \%$ of 163 had schistosomiasis. ${ }^{104}$ Skin infections are also common. Scabies was reported in $14 \%$ of 890 and $30 \%$ of 154 unaccompanied minors in two studies in Germany. ${ }^{100,105}$ Constant movement, disruption in their countries of origin, and emergencies are plausible reasons for the low vaccination coverage or knowledge of coverage described among unaccompanied minors. ${ }^{100,106}$ Among vaccine-preventable diseases, only hepatitis B has been frequently reported in unaccompanied minors; for example, $8 \%$ of 776 unaccompanied minors from 5 high-prevalence countries tested positive for hepatitis B in a cross-sectional study in Germany. ${ }^{105}$ Screening for
1 immunisation to measles, mumps, rubella, tetanus, and diphtheria is recommended when vaccination history is not known. ${ }^{101,106}$ Physical trauma is common during irregular crossings, resulting in cuts, tendon lacerations, fractures, and muscle contusions, which can leave longterm physical impairment. ${ }^{84,99}$ Finally, unaccompanied minors are probably at increased risk of sexually transmitted infections (STI) and unwanted pregnancies (although the prevalence is unreported) due to their vulnerability to sexual exploitation and increased risk taking that typically occurs during adolescence. This increased risk means that routine pregnancy testing and STI screening are relevant. Asymptomatic HIV and chlamydia are the most likely STIs to occur in 15 adolescents, ${ }^{107}$ and long-term consequences of sexual abuse include incontinence, infertility, and sexual dysfunction. ${ }^{85,107}$

\section{Mental health and development}

Mental health conditions-such as post-traumatic stress disorder, depression, anxiety, substance use, internalising and externalising behaviour, social withdrawal, and stress-are described extensively in literature of unaccompanied minors. ${ }^{89,92,95,96,108-111}$ A higher prevalence of post-traumatic stress disorder is reported among unaccompanied minors than among accompanied minors, ${ }^{92}$ with a difference in prevalence of $28 \%$ between these groups in Germany. ${ }^{112}$ Some studies report that the highest prevalence of post-traumatic stress disorder is among women and girls and people aged 17-18 years. For example, one study found that female unaccompanied minors were more likely to develop post-traumatic stress disorder compared with their male counterparts (odds ratio $1 \cdot 64 ; \mathrm{p}<0 \cdot 1) .{ }^{94}$ The high prevalence of mental health conditions among unaccompanied minors is in line with evidence linking social adversity to poor mental health, making screening and follow-up important to identify treatment need. Traumas that occur at young ages might have lasting consequences due to neurobiological effects on the developing brain ${ }^{53,86}$ and the effect of poor mental health on educational and personal development. Adolescence (the age period of most unaccompanied minors) is a crucial phase of mental development, as brain maturation is shaped by interaction with the environment. ${ }^{113-116}$ Unaccompanied minors might also develop considerable positive coping skills during migration [A: edit ok?] that can contribute to promoting their wellbeing once in the context of safety. As such, priorities for the mental health and development support for unaccompanied minors should emphasise safe recovery, assessment of complex social needs, and prompt psychosocial care. Such efforts acknowledge vulnerabilities and resilience during the process of ensuring young people's full rights.

\footnotetext{
The intersection between adverse childhood experiences, protective childhood experiences, and
}

See Online for appendix

,




\section{TLChild0339}

\section{Review}

\begin{tabular}{|c|c|c|c|}
\hline & $\begin{array}{l}\text { Location of study population } \\
\text { (number of studies) }\end{array}$ & $\begin{array}{l}\text { Population (size of } \\
\text { population) }\end{array}$ & Reported findings \\
\hline Baauw et a ${ }^{90}$ & $\begin{array}{l}\text { USA (26), Europe (13), Australia (8), } \\
\text { Canada (4), and New Zealand (2) }\end{array}$ & $\begin{array}{l}\text { Refugee children from Africa, } \\
\text { Asia, or the Middle East } \\
\text { ( } \mathrm{n}=223037)\end{array}$ & $\begin{array}{l}\text { High estimated prevalence was reported for anaemia (all regions 13.7\%, Africa 21.7\%, Asia 14.1\%, } \\
\text { and Middle East } 5.0 \% \text { ); haemoglobinopathies (all regions 3.7\%, Africa 7.3\%, Asia 16.0\%, and Middle } \\
\text { East 0.1\%); chronic hepatitis B (all regions 2.6\%, Africa 4.5\%, Asia 3.3\%, and Middle East 0.1\%); } \\
\text { latent tuberculosis (all regions 11.3\%, Africa 10.2\%, Asia 12.4\%, and Middle East 4.7\%); intestinal } \\
\text { infections (all regions 31.0\%, Africa 60.6\%, Asia 32.2\%, and Middle East 20.8\%); vitamin D } \\
\text { deficiency (all regions 44.6\%, Africa 54.1\%, Asia 42.4\%, and Middle East } 70.1 \% \text { ) }\end{array}$ \\
\hline Curtis et al $^{89}$ & $\begin{array}{l}\text { UK (12), Netherlands (7), Spain (6), } \\
\text { Sweden (5), Belgium (4), Norway (3), } \\
\text { Portugal (2), Scotland (2), Denmark } \\
\text { (2), Germany (2), Italy (2), Austria } \\
\text { (2), Switzerland (1), Greece (1), } \\
\text { Iceland (1), Ireland (1), and USA (1) }\end{array}$ & $\begin{array}{l}\text { Children }(<18 \text { years) who had } \\
\text { migrated across national } \\
\text { borders into, or within, } \\
\text { Europe; } 20 \text { studies included } \\
\text { unaccompanied minors } \\
(\mathrm{n}=28580)\end{array}$ & $\begin{array}{l}\text { Lower risk of binge drinking, tobacco use, and cannabis use was seen for migrants from Muslim- } \\
\text { majority countries than migrants from non-Muslim-majority countries; within low-income migrant } \\
\text { families, a transition to processed and energy-dense foods was reported; unaccompanied minors are } \\
\text { at greater risk of post-traumatic stress disorder than accompanied minors; not all migrant children } \\
\text { have poor mental health outcomes }\end{array}$ \\
\hline Kadir et a $\left.\right|^{12}$ & $\begin{array}{l}\text { Belgium (4), Germany (4), UK (4), } \\
\text { Denmark (3), Sweden (3), Greece } \\
\text { (2), Italy (1), Netherlands (1), } \\
\text { Norway (1), Austria (1), and } \\
\text { Spain (1) }\end{array}$ & $\begin{array}{l}\text { Asylum-seeking, refugee, } \\
\text { and undocumented children } \\
(\mathrm{n}=323457) \text { [A: edit } \\
\text { correct?] }\end{array}$ & $\begin{array}{l}\text { Low vaccination coverage and low immunity to vaccine-preventable diseases, including latent and } \\
\text { active tuberculosis, malaria, hepatitis B and hepatitis C, syphilis, and human T-lymphotropic virus } \\
\text { (type } 1 \text { and } 2 \text { ); physical trauma related to migrating (skin and tendon lacerations, fractures, and } \\
\text { muscle contusions; if left untreated, injuries can become infected); prevalence of iron deficiency } \\
\text { anaemia was } 4-18 \% \text {; dental problems had the highest prevalence among children who had } \\
\text { migrated to the UK (65\%) }\end{array}$ \\
\hline Kien et a ${ }^{92}$ & $\begin{array}{l}\text { Germany (8), Denmark (6), Sweden } \\
\text { (6), UK (5), Netherlands (4), Norway } \\
\text { (4), Belgium (3), Croatia (3), Italy } \\
\text { (3), Turkey (3), Austria (1), Finland } \\
\text { (1), Greece (1), and Slovenia (1) }\end{array}$ & $\begin{array}{l}\text { Children who were } \\
\text { unaccompanied or } \\
\text { accompanied and seeking } \\
\text { asylum, and adolescents or } \\
\text { refugee minors younger than } \\
21 \text { years }(\mathrm{n}=24786 \text { ) }\end{array}$ & $\begin{array}{l}\text { Results varied widely among studies; prevalence was } 19 \cdot 0-52 \cdot 7 \% \text { for post-traumatic stress disorder, } \\
10 \cdot 3-32 \cdot 8 \% \text { for depression; } 8 \cdot 7-31 \cdot 6 \% \text { for anxiety, and } 19 \cdot 8-35 \cdot 0 \% \text { for emotional and behavioural } \\
\text { problems; there was a higher prevalence of post-traumatic stress disorder, depression, and anxiety } \\
\text { among unaccompanied minors than among accompanied minors; most frequent pre-migration } \\
\text { stresses among unaccompanied minors were separation from or death of family members, armed } \\
\text { conflicts, and personal threats }\end{array}$ \\
\hline Mitra and Hodes ${ }^{93}$ & $\begin{array}{l}\text { UK (5), Netherlands (3), USA (2), } \\
\text { Germany (2), and Norway (1) }\end{array}$ & $\begin{array}{l}\text { Children who were } \\
\text { unaccompanied and seeking } \\
\text { asylum ( } n=1446)\end{array}$ & $\begin{array}{l}\text { Children in supportive living arrangements (eg, foster care) had a lower risk of post-traumatic stress } \\
\text { disorder and depression than did those in semi-independent care arrangements; one meta-analysis } \\
\text { found a benefit of foster care; those living in reception settings that restricted freedom had more } \\
\text { anxiety symptoms than those who did not live in restricted reception settings; unaccompanied } \\
\text { children were less likely to access mental health services and receive treatment than children who } \\
\text { were accompanied (eg, one study found that, although } 60 \% \text { of minors reported needing mental } \\
\text { health care, only } 12 \% \text { received it) }\end{array}$ \\
\hline Mohwinkel et a $\left.\right|^{94}$ & $\begin{array}{l}\text { Norway (3), Netherlands (3), UK (1), } \\
\text { Belgium (1), and Norway (1) }\end{array}$ & $\begin{array}{l}\text { Unaccompanied refugee } \\
\text { minors }(n=3018)\end{array}$ & $\begin{array}{l}\text { Female unaccompanied refugee minors were found to be more affected by post-traumatic stress } \\
\text { disorder or depressive symptoms than their male counterparts (one study found an odds ratio of } \\
1.64 \text { for girls); there is only weak evidence regarding other mental health outcomes }\end{array}$ \\
\hline Safi Keykaleh et al95 & Not specified & $\begin{array}{l}\text { Children and adolescents } \\
\text { who are refugees and } \\
\text { seeking asylum (population } \\
\text { size unreported) }\end{array}$ & $\begin{array}{l}\text { The most prevalent psychiatric disorders were post-traumatic stress disorder and depression; post- } \\
\text { traumatic stress disorder prevalence was directly related to the number of traumatic events; most } \\
\text { children who had guardians could receive their resettlement permit; safety in school, religious belief, } \\
\text { and degree of integration in society reduce the risk of post-traumatic stress disorder, depression, } \\
\text { and anxiety }\end{array}$ \\
\hline von Werthern et a $\left.\right|^{96}$ & $\begin{array}{l}\text { UK (7), Norway (6), Belgium (6), } \\
\text { Netherlands (5), Austria (2), Sweden } \\
\text { (2), Philippines (1), USA (1), } \\
\text { Germany (1), Finland (1), and } \\
\text { Italy (1) }\end{array}$ & $\begin{array}{l}\text { Unaccompanied refugee } \\
\text { minors }(n=11176)\end{array}$ & $\begin{array}{l}\text { Unaccompanied refugee minors are at risk of negative mental health developments; being a girl and } \\
\text { an adolescent ( } v \text { s being younger than } 17 \text { years old) increased the risk for negative mental health } \\
\text { developments; post-traumatic stress disorder prevalence was } 17.0-85.0 \% \text {, depression prevalence } \\
\text { was } 12.7-76.0 \% \text {, and anxiety prevalence was } 10.8-85.0 \%\end{array}$ \\
\hline \multicolumn{4}{|c|}{$\begin{array}{l}\text { *Unaccompanied minors are defined as a child or adolescent who is younger than } 18 \text { years, who is separated from relatives and is not being cared for by any other adult who, by law or custom, is responsible for } \\
\text { doing so. }\end{array}$} \\
\hline
\end{tabular}

\section{social determinants of health}

Forced migration and violence can affect the mental and physical health of children and adolescents through response to toxic stress, among other mechanisms. ${ }^{62}$ Toxic stress consists of both individual, stressful events a child goes through ${ }^{17}$ (ie, adverse childhood experiences [ACEs]) and the child's broader socioeconomic context (ie, social determinants of health). ${ }^{118}$ Each phase of migration implies a risk of ACEs, such as emotional, physical, and sexual abuse, and neglect. ${ }^{117}$ ACEs specific to migration include loss, chronic uncertainty, discrimination, acculturative stress, and insufficient basic social, material, and legal security. ${ }^{89,114}$ Unaccompanied minors are likely to have had more than one ACE, possibly enhancing the relative risk of complex effects. ${ }^{62,108,114}$ Multiple ACEs are frequently coupled with structural racism and adverse social determinants of health, such as missing educational or vocational opportunities and being without economic stability or protective social networks. Broader structural determinants of health, which affect children and 
adolescents more than other populations, are climate change and pervasive inequalities. ${ }^{118}$

Mental and physical health consequences associated with toxic stress include alcoholism, substance use, depression, suicide attempt, and risk of noncommunicable diseases during adulthood, including ischaemic heart disease and premature mortality. ${ }^{62,17,119}$ The mechanisms of these health outcomes include prioritising income generation over health-seeking behaviour, ${ }^{24}$ substandard accommodation, problematic 10 access to health care, and enduring nervous, endocrine, and immune system changes (termed allostatic load). ${ }^{120}$

Although these circumstances increase the vulnerability of unaccompanied minors, particularly during crises such as the COVID-19 pandemic, ${ }^{24,95}$ it is important to emphasise the resilience of unaccompanied minors. Studies have identified important experiences that enhance resilience, which we define as protective childhood experiences, including community feeling, belonging, appropriate accommodation, psychosocial care, and health and 20 educational schemes. ${ }^{109}$ Individual traits are important coping mechanisms, including faith, spirituality, and sense of purpose and responsibility towards the family that have been left behind..$^{53}$ Experiences that enhance these traits include having frequent contact with family and space to express religious beliefs. Protective childhood experiences are important as as they provide a way to respond to adversity, resulting in resilience. ${ }^{121}$ Thus, the social context and support an unaccompanied minor has is far from secondary and can have long-lasting benefits (figure).

Taken together, unaccompanied minors should receive a mental health, developmental, and nutritional assessment; infectious disease screening; examination of eyes, ear, nose, throat, and teeth; and evaluation of serum lead concentrations. ${ }^{97}$ Special consideration should be given to children who are at a higher risk, including victims of violence, sexual abuse, or trafficking. Such consideration implies knowledge about child welfare procedures and careful evaluation of the history and background of unaccompanied minors to assess not just their health, but also their safety. A culturally sensitive and traumainformed approach is mandatory when examining for signs of child abuse or violence. ${ }^{98}$ Thus, building trust is essential, especially among children who have received orders to stay away from, or have had negative experiences with, authorities. If possible, assessments should be made on multiple visits. ${ }^{97}$

\section{Legal implications}

Unaccompanied minors are entitled to legal protections set out in international treaties. How these treaties are applied in each country's domestic laws varies, even for countries that have ratified international legal obligations. Panel 2 gives examples of two countries (Uganda and Turkey) that have, and have not, integrated international treaties in their national policies.

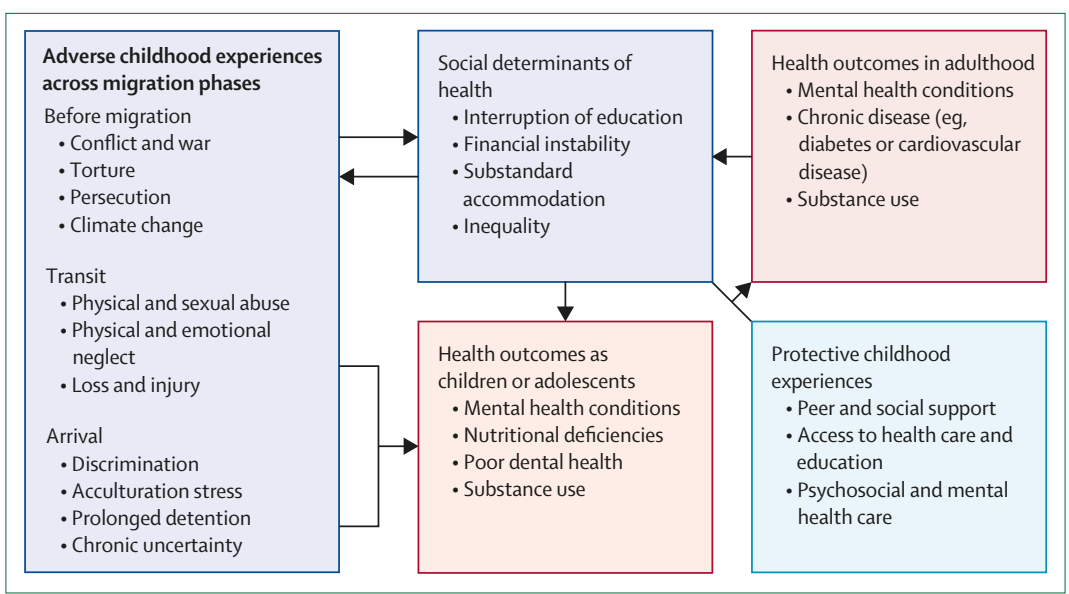

Figure: Intersection between adverse childhood experiences during migration and social determinants of health, and their long-term effects

Protective childhood experiences can act as a buffer so that adverse health conditions of childhood and adolescence are less prolonged and less severe in adulthood.

International legal instruments establish a wide spectrum of responsibilities of states towards unaccompanied minors, and all children, on their territory. The central instrument governing the rights of children is the 1989 UN CRC, which consolidates a wide range of human rights as they apply to children. It has been ratified by every member state of the UN (except the USA) and, as a result, has extensive applicability. Although we appreciate the risks faced by young adults and the debates around the period of adolescence, for this Review we have used the CRC definition of a child-ie, "every human being below the age of eighteen years unless under the law applicable to the child, majority is attained earlier". ${ }^{122}$ This definition provides a unifying principle for approaching the needs of unaccompanied minors, irrespective of nationality. However, if legal identification is non-existent or questionable, adolescent unaccompanied minors are subjected to unreliable age determination tests (panel 1). ${ }^{62}$ It is important to acknowledge that a child is primarily a child, before any definition, and that transitioning to adulthood can imply protection needs that extend beyond age 18 years.

Other CRC provisions include non-discrimination against a child on the basis of "race, colour, sex, language, religion, political or other opinion, national ethnic or social origin, property, disability, birth or other status". ${ }^{122}$ Additional international legislation, such as the Yogyakarta Principles Plus 10, obligates non50 discrimination based on gender. ${ }^{123}$ Although the Yogyakarta Principles Plus 10 include children (eg, principle 32), it is unclear how these apply to unaccompanied minors in practice. Since the 1990s, sexual orientation and gender identity have been included as grounds for asylum under the $1951 \mathrm{UN}$ Convention on the Status of Refugees. ${ }^{124,125}$ However, adolescents might be viewed as not fully aware of their 


\section{TLChild0339}

\section{Review}

sexuality, which challenges asylum procedures based on 1 sexual orientation and gender identity. ${ }^{126}$

Government measures that criminalise unaccompanied minors by treating them as illegal or deny them protections afforded to domestic children violate the nondiscrimination prohibition. Another core CRC principle is the best interests principle, which states, "in all actions concerning children, whether undertaken by public or private...bodies, the best interests of the child shall be a primary consideration." ${ }^{122}$ This means that policies that treat unaccompanied minors as migrants first (ie, excludable at the border, subject to detention, and

\section{Panel 2: Comparative policy analysis}

The effects of policies are a product of the perspective and interests that inform its development. How a policy context is framed is crucial to understanding the pathways through which policy emerges. ${ }^{138}$ In this sense, policies are not neutral but anchored to power dynamics. ${ }^{138}$ To understand the effect current policies have on unaccompanied minors globally, a deeper exploration of policy assumptions is needed. From an initial policy screening of six countries representative of the main migration corridors of unaccompanied minors (appendix pp 4-12), we selected policies from Turkey (an important transit route to Europe ${ }^{6}$ ) and Uganda (host of high numbers of unaccompanied refugees younger than 18 years). ${ }^{25}$ Our analysis is guided by Bacchi and Goodwin's method. ${ }^{139}$

For the past 6 years, Turkey has hosted the largest population of refugees and asylum seekers in the world. ${ }^{140}$ Turkey's conceptualisation of migrants as both a threat and a potential opportunity to leverage political power is anchored to complex historical tensions. ${ }^{141}$ In 2020, rising strains in the Turkey-EU relationship led to Turkish authorities threatening to "open the Greek-Turkish border" ${ }^{\prime 142}$ while, on the other side of its territory, along the border with Syria, a $764 \mathrm{~km}$ long concrete, razor-wire topped security wall was completed by 2018 [A: correct date? It had already been completed by 2020 when the threat was made. Please clarify this sentence]. ${ }^{143}$ The vulnerability of unaccompanied minors is recognised and provision of care is shared between international and domestic child protection laws led by Turkey's Ministry of Family, Labour, and Social Services. However, according to Turkish law, unaccompanied minors seeking international protection remain within the wider conceptualisation of migrants as potential threats to national security, with a burden on them to prove their innocence. ${ }^{144}$ Although policy states that unaccompanied minors should be treated in line with their best interests, ${ }^{144}$ no government documentation of how this occurs, or the number of unaccompanied minors in state care, could be found. Minors younger than 12 years should enter a child protection institution, and those aged 13-18 years should be in child protection units within refugee camps. ${ }^{145}$ Unaccompanied minors deemed ineligible to remain in Turkey can also be accommodated in removal centres. ${ }^{144}$ Although child protection law in immigration law emphasises a duty to support children's needs, the majority of the document details the response to juveniles involved in crime. ${ }^{146}$ Juvenile support ends at age 18 years, with no information detailing integration of unaccompanied minors into Turkish society. integration and respect. ${ }^{147}$ Uganda's 2019-24 Health Sector Integrated Refugee Response Plan (HSIRRP) ${ }^{148}$ reflects a commitment to international agreements that foster solidarity between countries. The HSIRRP highlights that refugees should have freedom of movement and access to services as nationals. The key issues are the high number of refugees (1.1 million at the time of policy writing, in 2018), and that "a parallel health system for refugees is unsustainable and promotes inequitable access to health". ${ }^{148}$ The policy proposes one single, resilient, state-led health-care system, accessible by refugees and nationals, as a sustainable, more financially efficient approach. Implementation of this policy requires workforce and infrastructure investment, and the policy acknowledges this requirement through the inclusion of non-governmental organisations and the private sector to fill funding and monitoring gaps. Accreditation for refugee health-care workers is proposed, allowing refugees to be self-reliant. The assumptions underlying this policy are based on health as a human right, regardless of nationality. However, the assumption of equality in a group with varied needs and levels of access, such as unaccompanied minors, is left unquestioned. Although there is a brief mention of separate service packages for adults and children, unaccompanied minors are not mentioned as a special category, despite Uganda hosting the second largest population of unaccompanied minor refugees in the world (40000 in 2019). ${ }^{25}$ The result of this gap is that young people who travel alone might not be able to access the benefits they need.

These policies represent alternative framings of migrants and, consequently, unaccompanied minors. As Turkey continues to have a global role in hosting large populations of refugees, conceptualising unaccompanied minors as potential threats to society risks devaluing their status as holders of universal and child human rights and therefore adversely affecting their health. Despite challenges in implementation, Uganda's representation creates the possibility for unaccompanied minors to be included in the country in positive ways that enhance health and wellbeing. 
ineligible for welfare services) and children second are challengeable. Many jurisdictions, including the EU, have included child protection as part of their migration control, including access to guardians, child-friendly shelter, and specialist staff training, flowing from the best interests principle. ${ }^{127}$

Article 22 of the CRC obliges states to ensure that refugee or asylum-seeking children should "receive appropriate protection and humanitarian assistance in the enjoyment of applicable rights". ${ }^{122}$ Among applicable rights, are those set out in the 1951 UN Convention on the Status of Refugees as amended by the 1967 protocol, including protection from refoulement (ie, unaccompanied minors cannot be forcibly expelled to a place where they face life-threatening risks). ${ }^{122}$ It is also the state's obligation to avoid family separation against the child's will. Measures that indiscriminately impose such expulsions or separations on unaccompanied minors violate core humanitarian principles. There is evidence of authorities justifying a restriction on rights on the basis of health emergencies or terrorism, disregarding the Siracusa Principles that allow strictly evidence-based, proportional, and legal restrictions in the name of public health. ${ }^{128}$ These measures marginalise irregular migrant groups, such as unaccompanied minors.

Finally, all children have the right to have their birth registered and to acquire a nationality. Stateless children, including unaccompanied minors, can be affected by an acute violation of these fundamental legal identity rights, facing challenges securing eligibility documents for mobility, state services, and protection. Health professionals involved in maternity services have an important role in ensuring that the relevant authorities implement their obligations in this domain by ensuring the child has a birth registration.

\section{Conclusions and recommendations}

In this Review, we aimed to outline all aspects relevant for advocacy of better health for unaccompanied minors. However, the evidence presented is non-exhaustive, given the absence of comprehensive migration and health data about unaccompanied minors. Although we gave a global perspective, understanding the intricacies related to specific contexts is fundamental to building local capacity to appropriately manage unaccompanied minors. We did not seek to map practices and intervention strategies, which could be a potential focus for future research.

The irregular migration of children is a complex topic 5 that explicitly shows the brutality of migration enforcement, structural racism and inequities, and violence. Inadequate data on unaccompanied minors might reflect the denial of governments to take full responsibility for their health and the inadequate 55 investment in health and child protection as crucial components of migration governance. Governments should admit their contribution to migration-eg, by investing in wars, outsourcing low-wage labour, exploiting resources, and contributing to climate change-instead of manipulating migration data in xenophobic discourses to the public in host countries. Currently, child protection systems are unsuitable-two of the most common problems that occur with unaccompanied minors, age disputes and disappearances (panel 1), still do not have apparent solutions. A joint effort to orient advocacy, politics, investment, and research towards integrated, resilient and efficient health, education, and welfare systems that can benefit host and migrant populations is more crucial than ever for global justice. Child-health professionals have a crucial role in advocating for improvements in health and the determinants of health.

Recommendations from this Review are based on evidence provided, binding legal obligations, and child protection principles. Challenging indifference to migrant and child rights, usually driven by competing economic interests under the name of national security, means challenging the xenophobic and manipulated discourse that conveys recommendations for these rights as charity (at best) or theft (at worst) of resources. Although it is beyond the scope of this Review to assess the historical, social, and economic circumstances that drive forced migration, it is crucial to understand the complexity and roots of migration.

We propose three specific recommendations that are interconnected and based on the principle that children are children, regardless of nationality. First, non-discrimination in access to health care should be a priority, given the long-term consequences that migration can have on children and adolescents. Unaccompanied minors should have guaranteed access to school and health services, including transportation and information availability, and appropriate training of teachers and health professionals is essential. ${ }^{129}$ While family reunification checks are done, safe accommodation, basic services, and the appointment of a guardian are essential in guaranteeing the health and wellbeing of unaccompanied minors. Access to physical and mental health care should be made routinely available in migratory checkpoints and through mobile health clinics, including sexual and reproductive health services for victims of sexual violence. Clear information campaigns on how to access health services are also required.

Second, there needs to be adequate, good quality, and ethically collected data that can accurately reflect the migration of unaccompanied minors. Indeed, ethical and data protection frameworks should govern the collection, use, sharing, reporting, and dissemination of migration health-related data, particularly for unaccompanied minors. Part of this robust framework should include direct interactions with these children and adolescents that form the evidence base, age and gender disaggregation of data, standardisation of definitions (including definitions on violence against children ${ }^{130}$ ), and incentives for national 
data collection on unaccompanied minors. Incentives 1 refer to concrete financial resource commitments (both at the UN and national level) to prioritising children's healthy development, including appropriately trained staff and coordination between immigration, child protection, and health authorities at the national level. ${ }^{131}$ Specific methods for data collection are available in existing toolkits. ${ }^{132,133}$ Excellent guidelines also exist for holistic age assessment identification procedures. ${ }^{134,135}$ Agencies collecting data on unaccompanied minors should have robust training and 10 confidentiality that ensure data cannot be used by border enforcement purposes. Training should focus on individualised, gender-sensitive, and child-friendly processing that emphasises the right to be heard. Ideally, a separate body of migration officials should be appointed to 15 deal only with children or people who are considered vulnerable.

Third, unaccompanied minors should be explicitly included in national migration and health policies, following international treaties, to guarantee the 2 protection of their best interests. Unaccompanied minors should be managed through their inclusion in domestic child welfare systems, in communication with migration authorities, and there should be alternatives to detention. Deportation and so-called voluntary return should be 25 assessed not just on the basis of immediate risks but also from a health perspective, including stability and longterm development. ${ }^{136}$ Standardisation of reception and care of unaccompanied minors should be shared between countries, anticipating influxes with appropriate humanitarian corridors and resettlement incentives that include support of local communities. Predictive analytics (ie, the use of existing data to predict events) aids this anticipation of humanitarian need and is already in use by the UN Centre for Humanitarian Data. ${ }^{137}$ Such analysis should be 35 included in governments' budget planning, policy implementation, and monitoring, with accountability for the use of resources to avoid corruption. Policy should focus on the integration of unaccompanied minors, through investment in resilient health and education systems that benefit both young migrants and young people in host countries. As unaccompanied minors are mostly older adolescents, educational access should include higher education or vocational training. With appropriate measures for inclusion, such as language 4 classes and activities to combat prejudice, migration can be beneficial for the host country's economy in the long term. Finally, child-health professionals should be Consulted when migration and health policies are developed.

\section{Contributors}

SCM and DD conceived the work. SCM wrote the first draft and the Uganda policy analysis. DD oversaw the manuscript development. JB wrote the legal implications section and had substantial input on the recommendations section. LCNW wrote the Turkey policy analysis and oversaw the data related to trafficking. RB was senior lead on the policy analysis. LE wrote the France case study and OOG wrote the Mexico case study. VD collaborated in the policy analysis screening and oversaw the

\section{Search strategy and selection criteria}

For the review of health outcomes, we searched PubMed, Embase, PsychINFO, and Google Scholar from Jan 1, 2000, to Sept 9, 2020, with the search terms: "(unaccompanied or separated) AND (minor* or child* or adolescent*) AND (migration or migration transit) AND (health or health profile or health need) OR (mental health or depression or anxiety or post-traumatic stress disorder or substance or schizophrenia) OR (risk* or violence or abuse or trafficking or exploitation)". Additional references were added by searching reference lists and from recommendations. We included review studies describing physical health, morbidity profiles, or mental health that included unaccompanied minors as a population. We excluded articles if the health profile of unaccompanied minors was not the main focus, if unaccompanied minors were not included as disaggregated population, and if the review was included in another review. We also searched migration data portals, government websites, nongovernmental organisation reports, and country reports for references [A: edit ok?]. The combined searches for these sections led to the inclusion of 125 references in the review and additional 23 references were added by coauthors.

data related to intimate partner violence and gender-based violence. KW and RA contributed to the trends and data section and the recommendations regarding data. All authors contributed to revising, commenting, and modifying the final draft.

\section{Declaration of interest}

We declare no competing interests.

\section{Acknowledgments}

We thank the insightful comments of the reviewers. SCM thanks Consejo Nacional de Ciencia y Tecnología (Mexico City, Mexico) for a personal scholarship.

Editorial note: the Lancet Group takes a neutral position with respect to territorial claims in published maps and institutional affiliations.

References [A: we will renumber these references according to Lancet style in the proof stage]

1 UN. General comment no 6 (2005): treatment of unaccompanied and separated children outside their country of origin. Sept 1, 2005. https://www.refworld.org/docid/42dd174b4.html (accessed June 12, 2021).

2 Bhabha JA, Abel G. Children and unsafe migration. In: McAuliffe M, Khadria B, eds. IOM world migration report. Geneva: International Organisation for Migration, 2019: 231-52.

3 UNICEF. A child is a child. May, 2017. https://www.unicef.org/ media/49571/file/UNICEF_A_child_is_a_child_May_2017_EN.pdf (accessed June 12, 2021).

504 Allsopp JCE, Chase E. Best interests, durable solutions and belonging: policy discourses shaping the futures of unaccompanied migrant and refugee minors coming of age in Europe. J Ethn Migr Stud 2019; 45: 293-311.

5 Eide K, Hjern A. Unaccompanied refugee children-vulnerability and agency. Acta Paediatr 2013; 102: 666-68.

556 Jovanovic K, Besedic J. Struggling to survive. Unaccompanied and separated children travelling the Balkans route. Belgrade: Save The Children, 2019. 
7 Humphris RS, Sigona N. The bureaucratic capture of child migrants: effects of in/visibility on children on the move. Antipode 2019; 51: 1495-514.

8 Hedlund D. Constructions of credibility in decisions concerning unaccompanied minors. Int J Migr Health Soc Care 2017; 13: 157-72.

9 Derluyn I, Broekaert E. Unaccompanied refugee children and adolescents: the glaring contrast between a legal and a psychological 5 perspective. Int J Law Psychiatry 2008; 31: 319-30.

10 Anderson K, Apland K, Yarrow E. Unaccompanied and unprotected: the systemic vulnerability of unaccompanied migrant children in South Africa. In: Liefaard T, Sloth-Nielsen J, eds. The United Nations Convention on the Rights of the Child. Leiden: Brill Nijhoff, 2017: 361-89.

11 Litzkow J. MMC adapts its 4Mi program to assess the impact of COVID-19 on refugees and migrants. Mixed Migration Centre. April 1, 2020. http://www.mixedmigration.org/articles/mmc-adaptsits-4mi-program-to-assess-the-impact-of-covid-19-on-refugees-andmigrants/ (accessed June 12, 2021).

12 Brittle RD, Desmet E. Thirty years of research on children's rights in the context of migration - towards increased visibility and recognition of some children, but not all? Int J Child Rights 2020; 28: 36-65.

13 Gall L. Hungary weaponizes coronavirus to stoke xenophobia. Human Rights Watch. March 19, 2020. https://www.hrw.org/ news/2020/03/19/hungary-weaponizes-coronavirus-stokexenophobia (accessed June 12, 2021).

14 Bhabha J, Dottridge M. Child rights in the global compacts: working document. Recommendations for protecting, promoting and implementing the human rights of children on the move in the proposed global compacts. Initiative for Child Rights in the Global Compacts. June 24, 2017. https://resourcecentre.savethechildren. net/node/13913/pdf/working-document-29-june-2017.pdf (accessed June 12, 2021).

15 Orcutt M, Mussa R, Hiam L, et al. EU migration policies drive health crisis on Greek islands. Lancet 2020; 395: 668-70.

16 UN High Commissioner for Refugees. UNHCR global trendsforced displacement in 2018. June 18, 2019. https://www.unhcr.org/ statistics/unhcrstats/5d08d7ee7/unhcr-global-trends-2018.html (accessed June 12, 2021).

17 Laczko F, Brian T. Fatal journeys-tracking lives lost during migration. Geneva: International Organisation for Migration, 2014.

18 Singleton AB. Data: creating the empirical base for development of child migration policy and protection. In: Bhabha J, Kanics J, Senovilla Hernández D, eds. Research handbook on child migration. Cheltenham: Edward Elgar Publishing, 2018: 334-44.

19 International Organization for Migration. Child migrants: how little we know. Global Migration Data Analysis Centre. November, 2017. https://publications.iom.int/system/files/pdf/gmdac_data_ briefing_series_issue_10.pdf (accessed June 12, 2021).

20 UNICEF. Child migration. April, 2021. https://data.unicef.org/ topic/child-migration-and-displacement/migration/ (accessed June 12, 2021).

21 UN Department of Economic and Social Affairs. World population prospects 2019. https://population.un.org/wpp/Graphs/ DemographicProfiles/Line/900 (accessed June 12, 2021).

22 van de Glind H. Migration and child labour. Exploring child migrant vulnerabilities and those of children left behind. Geneva: International Labour Office, 2010.

23 Yaqub S. Child migrants with and without parents: census-based estimates of scale and characteristics in Argentina, Chile and South Africa. February, 2009. https://www.unicef-irc.org/publications/pdf/ idp_2009_02.pdf (accessed June 12, 2021).

24 UNICEF. Lost at home. The risks and challenges for internally displaced children and the urgent actions needed to protect them. May, 2020. https://data.unicef.org/resources/lost-at-home-risksfaced-by-internally-displaced-children/ (accessed June 12, 2021).

25 UN High Commissioner for Refugees. UNHCR global trends forced displacement 2019. June 18, 2021. https://www.unhcr.org/ statistics/unhcrstats/5ee200e37/unhcr-global-trends-2019.html (accessed June 12, 2021).

26 Mullally S, Raissian C. A child rights response to child migration and migrant children at risk. International Bar Association. September, 2019. https://www.ibanet.org/ MediaHandler?id=a9e81c7a-56f1-43ca-93ea-091c3e2c8832 (accessed June 12, 2021).
127 You D, Lindt N, Allen R, Hansen C, Beise J, Blume S. Migrant and displaced children in the age of COVID-19: how the pandemic is impacting them and what we can do to help. Migration Policy Practice. https://www.unicef.org/media/83546/file/Migrant-anddisplaced-children-in-the-age-of-COVID-19.pdf (accessed June 12, 2021).

28 McAlpine A, Hossain M, Zimmerman C. Sex trafficking and sexual exploitation in settings affected by armed conflicts in Africa, Asia and the Middle East: systematic review. BMC Int Health Hum Rights 2016; 16: 34

29 UN General Assembly Human Rights Council. Impact of coronavirus disease on different manifestations of sale and sexual exploitation of children. Jan 22, 2021. https://reliefweb.int/report/ world/impact-coronavirus-disease-different-manifestations-saleand-sexual-exploitation (accessed June 12, 2021).

30 Portal MD. Human trafficking. May 6, 2021. https:// migrationdataportal.org/themes/human-trafficking (accessed June 12, 2021).

31 Europol. Child trafficking: who are the victims and the criminal networks trafficking them in and into the EU. Oct 18, 2018. https:// www.europol.europa.eu/newsroom/news/child-trafficking-who-arevictims-and-criminal-networks-trafficking-them-in-and-eu (accessed June 12, 2021).

32 Habib RR, Ziadee M, Abi Younes E, Harastani H. Syrian refugee child workers: gender differences in ergonomic exposures and musculoskeletal health. Appl Ergon 2020; 83: 102983.

33 Blanpied W. Child labour: the new reality for refugee children. London: Save the Children International, 2017.

34 International Labour Organization. Global estimates of child labour: results and trends, 2012-2016. Geneva, International Labour Organization, 2017.

35 UN Office on Drugs and Crime. Global report on trafficking in persons. Vienna: United Nations Office on Drugs and Crime, 2018.

36 UNICEF. "No mother wants her child to migrate" vulnerability of children on the move in the horn of Africa. Florence: United Nations Children's Fund, 2019.

37 Capaldi M. Rethinking independent child migration in Thailand: victims of exploitation or competent agents? JPSS 2015; 23: 17-33.

3038 West A. Children on the move in South-East Asia. Why child protection systems are needed. London: Save the Children UK, 2008.

39 Summers H. Child refugees held in 'harrowing' conditions acros south-east Asia. June 13, 2017. https://www.theguardian.com/globaldevelopment/2017/jun/13/child-refugees-held-in-harrowingconditions-across-south-east-asia-report (accessed June 12, 2021).

40 Button L. Unlocking childhood: current immigration detention practices and alternatives for child asylum seekers and refugees in Asia and the Pacific. Melbourne, VIC: Save the Children Australia, 2017.

41 Eurostat. Asylum applicants considered to be unaccompanied minors by citizenship, age and sex-annual data 2020. https:// appsso.eurostat.ec.europa.eu/nui/show.do?dataset=migr asyunaa\&lang=en (accessed June 12, 2021).

42 Asylum Information Database, European Council on Refugees and Exiles. Country report: United Kingdom. Dec 31, 2019. https:// asylumineurope.org/wp-content/uploads/2020/03/reportdownload_aida_uk_2019update.pdf (accessed June 12, 2021).

xx1 Asylum Information Database, European Council on Refugees and Exiles. Country report: Greece. Dec 31, 2019. https:// asylumineurope.org/wp-content/uploads/2020/07/reportdownload_aida_gr_2019update.pdf (accessed June 12, 2021).

xx2 Asylum Information Database, European Council on Refugees and Exiles. Country Report: Germany. Dec 31, 2019. https:// asylumineurope.org/wp-content/uploads/2020/07/reportdownload_aida_de_2019update.pdf (accessed June 12, 2021).

xx3 Asylum Information Database, European Council on Refugees and Exiles. Country Report: Belgium. Dec 31, 2019. https:// asylumineurope.org/wp-content/uploads/2020/07/reportdownload_aida_be_2019update.pdf (accessed June 12, 2021).

43 Europa. Almost 14000 unaccompanied minors among asylum seekers registered in the EU in 2019. April 28, 2020. [Web address] (accessed June 12, 2021). [A: please provide accessed on date and web address

44 Weber B. The myth of the closed Balkan route. 2017. https://www. 
fes.de/en/displacement-migration-integration/article-page-flightmigration-integration/the-myth-of-the-closed-balkan-route (accessed June 12, 2021).

45 Odysseus Network. Memorandum of understanding on cooperation in the fields of development, the fight against illegal immigration, human trafficking and fuel smuggling and on reinforcing the security of borders between the State of Libya and the Italian Republic. 2017. https://eumigrationlawblog.eu/wpcontent/uploads/2017/10/MEMORANDUM_translation_ finalversion.doc.pdf (accessed June 12, 2021).

46 Mars A, Marcial Pérez D. Trump llega a un acuerdo migratorio con México y retira la amenaza de aranceles. June 8, 2019. https://elpais. com/internacional/2019/06/08/estados_unidos/1559954214_505851. html (accessed June 12, 2021).

47 Alandete D. Biden logra militarizar el control migratorio en Centroamérica. April 13, 2021. https://www.abc.es/internacional/ abci-biden-logra-militarizar-control-migratoriocentroamerica-202104130125_noticia.html (accessed June 12, 2021).

48 US Customs and Border Protection. US border patrol southwest border apprehensions by sector. 2020. https://www.cbp.gov/ newsroom/stats/sw-border-migration/usbp-sw-borderapprehensions (accessed June 12, 2021).

49 Wong T, De Roche G, Rojas Venzor J. The migrant 'surge' at the US southern border is actually a predictable pattern. Washington Post. March 25, 2021. https://www.washingtonpost.com/ politics/2021/03/23/theres-no-migrant-surge-us-southern-borderheres-data/ (accessed June 12, 2021).

50 Kielland A. Child labor migration in Benin; incentive, constraint or agency. Saarbrucken: Omniscriptum, 2008.

51 Thorsen D. Child migrants in transit strategies to become adult in rural Burkina Faso. Paper presented to Children and Youth in Emerging and Transforming Societies. Oslo: Development Research Centre on Migration, Globalisation and Poverty, 2005.

52 Office of Refugee Resettlement. Facts and data. 2019. https://www. acf.hhs.gov/orr/about/ucs/facts-and-data (accessed June 12, 2021).

53 Carlson BE, Cacciatore J, Klimek B. A risk and resilience perspective on unaccompanied refugee minors. Soc Work 2012; 57: 259-69.

54 Kanics J, Senovilla-Hernandez D, Touzenis K. Migrating alone: unaccompanied and separated children's migration to Europe. Paris: United Nations Educational, Scientific and Cultural Organization, 2010.

55 UNICEF. UNICEF humanitarian action for children 2020. Paris: United Nations Educational, Scientific and Cultural Organization, 2020.

56 Menjívar C, Perreira KM. Undocumented and unaccompanied: children of migration in the European Union and the United States. J Ethn Migr Stud, 2019; 45: 197-217.

57 Pérez REP. ¿Migrantes o refugiados? La crisis humanitaria de menores no acompañados que México y Estados Unidos no reconoce. RIEM 2017; 7: 245-74

58 Bourgault S, Peterman A, O’Donnell M. Violence against women and children during COVID-19-one year on and 100 papers. https://www.cgdev.org/publication/violence-against women-and-children-during-covid-19-one-year-and-100-papersfourth (accessed June 12, 2021).

59 NeMoyer A, Rodriguez T, Alvarez K. Psychological practice with unaccompanied immigrant minors: clinical and legal considerations. Transl Issues Psychol Sci 2019; 5: 4-16.

60 Ataiants J, Cohen C, Riley AH, Tellez Lieberman J, Reidy MC, Chilton M. Unaccompanied children at the United States border, a human rights crisis that can be addressed with policy change. J Immigr Minor Health 2018; 20: 1000-10.

61 Marzouk J. Ethical and effective representation of unaccompanied immigrant minors in domestic violence-based asylum cases. Clin Law Rev 2015; 22: 395.

62 Abubakar I, Aldridge RW, Devakumar D, et al. The UCL-Lancet Commission on Migration and Health: the health of a world on the move. Lancet 2018; 392: 2606-54.

63 Najar A. Aranceles de Trump: los riesgos del "muro militar" con el que el gobierno de AMLO se comprometió a frenar la migración para evitar los aranceles de EE.UU. June 9, 2019. https://www.bbc.com/mundo/noticias-americalatina-48570886 (accessed June 12, 2021).
164 Digidiki V, Bhabha J. Sexual abuse and exploitation of unaccompanied migrant children in Greece: identifying risk factors and gaps in services during the European migration crisis. Child Youth Serv Rev 2018; 92: 114-21.

65 UNICEF. Harrowing journeys: children and youth on the move across the Mediterranean Sea, at risk of trafficking and exploitation. Sept, 2017. https://data.unicef.org/resources/harrowing-journeys/ (accessed June 12, 2021).

66 Thompson AT, Swanson K, Blue S, Hernandez OM. Re-conceptualising agency in migrant children from central America and Mexico. J Ethn Migr Stud 2019; 45: 235-53.

67 Laczko F, Black J, Singleton A, eds. Fatal journeys. Missing migrant children. Berlin: International Organization for Migration Global Migration's Data Analysis Centre, 2019.

68 Huynh J. La Charla: documenting the experience of unaccompanied minors in immigration court. J Ethn Migr Stud 2018; 47: 616-30.

69 Antony MG, Thomas RJ. "Stop sending your kids across our border:" discursively constructing the unaccompanied youth migrant. J Int Intercult Commun 2017; 10: 4-24.

70 Lelliott J. Smuggled and trafficked unaccompanied minors: towards a coherent, protection-based approach in international law. Int J Refug Law 2017; 29: 238-69.

71 Meloni F. The ambivalence of belonging: the impact of illegality on the social belonging of undocumented youth. Anthropol Q 2019; 92: 451-79.

2072 Bowerman E. Risks encountered after forced removal: the return experiences of young Afghans. Forced Migr Rev 2017; 54: 78-80.

73 European Migration Network. How do EU member states treat cases of missing unaccompanied minors? Brussels: European Commission, 2020.

74 Kalverboer MB, Beltman D, van Os C, Zijlstra E. The best interests of the child in cases of migration: assessing and determining the best interests of the child in migration procedures. Int J Child Rights 2017; 25: 114-39.

75 International Federation of the Red Cross and Red Crescent Societies. Alone and unsafe: children, migration and sexual and gender-based violence. 2018. https://media.ifrc.org/ifrc/wp-content/ uploads/2018/12/181126-AloneUnsafe-Report-EN-web.pdf (accessed June 12, 2021).

76 Selvarajah S, Deivanayagam TA, Lasco G, et al. Categorisation and minoritisation. BMJ Glob Health 2020; 5: e004508.

77 Weigl M, Strizek J. Substance use among unaccompanied minor aged and young refugees in Vienna. Eur J Public Health 2018; 28: cky047.014.

3578 Magnusson M-M, Ivert A-K, eds. Patterns of drug use among unaccompanied refugee minors. Stockholm Criminology Symposium; Stockholm; June 10-12, 2019.

79 Patel K, Buffin J, Khurana J, Underwood S. Young refugees and asylum seekers in Greater London: vulnerability to problematic drug use. London: Greater London Authority, 2004.

80 Sawyer CB, Márquez J. Senseless violence against central American

40 unaccompanied minors: historical background and call for help. J Psychol 2017; 151: 69-75

81 Estefan LF, Ports KA, Hipp T. Unaccompanied children migrating from central America: public health implications for violence prevention and intervention. Curr Trauma Rep 2017; 3: 97-103.

82 Pérez R. Crossing the border from boyhood to manhood: male youth experiences of crossing, loss, and structural violence as unaccompanied minors. Int J Adolesc Youth 2014; 19: 67-83.

83 Oliveira C, Keygnaert I, Oliveira Martins MDR, Dias S. Assessing reported cases of sexual and gender-based violence, causes and preventive strategies, in European asylum reception facilities. Global Health 2018; 14: 48.

84 Zijlstra AE, Menninga MC, van Os ECC, Kalverboer ME. They ask for protection: an exploratory study into experiences with violence among unaccompanied refugee children in Dutch reception facilities. Child Abuse Negl 2020; 103: 104442.

85 Chynoweth SK, Freccero J, Touquet H. Sexual violence against men and boys in conflict and forced displacement: implications for the health sector. Reprod Health Matters 2017; 25: 90-94.

55 Cardoso JB. Running to stand still: trauma symptoms, coping strategies, and substance use behaviors in unaccompanied migrant youth. Child Youth Serv Rev 2018; 92: 143-52. 
87 Cook MC, Barnert E, Ijadi-Maghsoodi R, Ports K, Bath E. Exploring mental health and substance use treatment needs of commercially sexually exploited youth participating in a specialty juvenile court. Behav Med 2018; 44: 242-49.

88 Patton GC, Sawyer SM, Santelli JS, et al. Our future: a Lancet commission on adolescent health and wellbeing. Lancet 2016; 387: 2423-78.

89 Curtis P, Thompson J, Fairbrother H. Migrant children within Europe: a systematic review of children's perspectives on their health experiences. Public Health 2018; 158: 71-85.

90 Baauw A, Kist-van Holthe J, Slattery B, Heymans M, Chinapaw M, van Goudoever $H$. Health needs of refugee children identified on arrival in reception countries: a systematic review and metaanalysis. BMJ Paediatr Open 2019; 3: e000516.

91 Kadir A, Battersby A, Spencer N, Hjern A. Children on the move in Europe: a narrative review of the evidence on the health risks, health needs and health policy for asylum seeking, refugee and undocumented children. BMJ Paediatr Open 2019; 3: bmipo-2018-000364.

92 Kien C, Sommer I, Faustmann A, et al. Prevalence of mental disorders in young refugees and asylum seekers in European Countries: a systematic review. Eur Child Adolesc Psychiatry 2019; 28: $1295-310$

93 Mitra R, Hodes M. Prevention of psychological distress and promotion of resilience amongst unaccompanied refugee minors in resettlement countries. Child Care Health Dev 2019; 45: 198-215.

94 Mohwinkel L-M, Nowak AC, Kasper A, Razum O. Gender differences in the mental health of unaccompanied refugee minors in Europe: a systematic review. BMJ Open 2018; 8: e022389.

95 Safi Keykaleh M, Jahangiri K, Tabatabaie S. Mental health challenges in immigrant and refugee children and adolescents: a systematic review. Health Emerg Disasters Q 2017; 3: 3-10.

96 von Werthern M, Grigorakis G, Vizard E. The mental health and wellbeing of unaccompanied refugee minors (URMs). Child Abuse Negl 2019; 98: 104146.

97 Minhas RS, Graham H, Jegathesan T, Huber J, Young E, Barozzino T. Supporting the developmental health of refugee children and youth. Paediatr Child Health 2017; 22: 68-71.

98 Caring for Kids New to Canada. A mindful approach: assessing child maltreatment in a multicultural setting. April, 2018. https://www.kidsnewtocanada.ca/screening/maltreatment (accessed June 12, 2021).

99 Devi S. Unaccompanied migrant children at risk across Europe. Lancet 2016; 387: 2590

100 Kloning T, Nowotny T, Alberer M, Hoelscher M, Hoffmann A Froeschl G. Morbidity profile and sociodemographic characteristics of unaccompanied refugee minors seen by paediatric practices between October 2014 and February 2016 in Bavaria, Germany. BMC Public Health 2018; 18: 983.

101 Hjern A, Kling S. Health care needs in school-age refugee children. Int J Environ Res Public Health 2019; 16: 4255.

102 Devakumar D, Hall J, Lawn J, Qureshi Z. Oxford textbook of global health of women, newborns, children, and adolescents. Oxford: Oxford University Press, 2019.

103 Magdalini P, Narring F, Chamay-Weber C. Health care needs for unaccompanied asylum-seeking adolescents: a retrospective study from an adolescent health unit in Switzerland. J Adolesc Health 2018; 62: S108-09.

104 Williams B, Boullier M, Cricks Z, et al. Screening for infection in unaccompanied asylum-seeking children and young people. Arch Dis Child 2020; 105: 530-32.

105 Janda A, Eder K, Fressle R, et al. Comprehensive infectious disease screening in a cohort of unaccompanied refugee minors in Germany from 2016 to 2017: a cross-sectional study. PLoS Med 2020; 50 17: e1003076.

106 Mipatrini D, Stefanelli P, Severoni S, Rezza G. Vaccinations in migrants and refugees: a challenge for European health systems. A systematic review of current scientific evidence. Pathog Glob Health 2017; 111: 59-68.

107 Mason-Jones AJ, Nicholson P. Structural violence and marginalisation. The sexual and reproductive health experiences of 55 separated young people on the move. A rapid review with relevance to the European humanitarian crisis. Public Health 2018;
158: 156-62.

108 Hodes M, Jagdev D, Chandra N, Cunniff A. Risk and resilience for psychological distress amongst unaccompanied asylum seeking adolescents. J Child Psychol Psychiatry 2008; 49: 723-32.

109 Cayabyab CR, O’Reilly P, Murphy AM. Psychological morbidity among forcibly displaced children-a literature review. Ir J Med Sci 2020; 189: 991-97.

110 Pine DS, Costello J, Masten A. Trauma, proximity, and developmental psychopathology: the effects of war and terrorism on children. Neuropsychopharmacology 2005; 30: 1781-92.

111 Teitel YH. Medical and mental health needs of unaccompanied, undocumented adolescents in New York City: a qualitative, interview-based study. J Adolesc Health 2016; 58 (suppl 1): S44-45.

112 Müller LRF, Büter KP, Rosner R, Unterhitzenberger J. Mental health and associated stress factors in accompanied and unaccompanied refugee minors resettled in Germany: a crosssectional study. Child Adolesc Psychiatry Ment Health 2019; 13: 8.

113 Hughes N, Ungar M, Fagan A, et al. Health determinants of

15 adolescent criminalisation. Lancet Child Adolesc Health 2020; 4: $151-62$.

114 Seglem KB. Interpersonal risks, resources and depression symptoms among resettled unaccompanied minor refugees. 2007. https://www.duo.uio.no/handle/10852/18320 (accessed June 12, 2021).

115 Chase E, Rezaie H, Zada G. Medicalising policy problems: the mental health needs of unaccompanied migrant young people. Lancet 2019; 394: 1305-07.

116 Alami R. From war to refuge: a literature review of the psychosocial impact of pre- and post-migration experience on the Syrian child refugee. PhD thesis, Alliant International University, 2020: 13886128.

25117 Felitti VJ. The relation between adverse childhood experiences and adult health: turning gold into lead. Perm J 2002; 6: 44-47.

118 Marmot M, Friel S, Bell R, Houweling TA, Taylor S. Closing the gap in a generation: health equity through action on the social determinants of health. Lancet 2008; 372: 1661-69.

119 Brown DW, Anda RF, Tiemeier H, et al. Adverse childhood experiences and the risk of premature mortality. Am J Prev Med 2009; 37: 389-96.

120 Danese A, McEwen BS. Adverse childhood experiences, allostasis, allostatic load, and age-related disease. Physiol Behav 2012; 106: 29-39.

121 Ciaccia KA, John RM. Unaccompanied immigrant minors: where to begin. J Pediatr Health Care 2016; 30: 231-40.

35122 UN Human Rights Office of High Commissioner. UN Convention on the Rights of the Child: adopted and opened for signature, ratification and accession by General Assembly resolution 44/25 of 20 November 1989 entry into force 2 September 1990, in accordance with article 49. https://www.ohchr.org/en/professionalinterest/ pages/crc.aspx (accessed June 12, 2021).

123 Yogyakarta Principles Plus 10. Nov 10, 2017. https:// yogyakartaprinciples.org/principles-en/yp10/ (accessed June 12, 2021).

124 UN High Commissioner for Refugees. Guidelines on international protection no 9; claims to refugee status based on sexual orientation and/or gender identity within the context of Article 1A(2) of the 1951 convention and/or its 1967 protocol relating to the status of refugees. 2012. https://www.unhcr.org/509136ca9.pdf (accessed June 12, 2021).

125 International Lesbian, Gay, Bisexual, Trans and Intersex Association. Protecting the rights of LGBTI asylum seekers and refugees in the reform of the Common European Asylum System. December, 2016. https://ilga-europe.org/sites/default/files/ Attachments/ilga-europe_-_protecting_the_rights_of_lgbti_asylum seekers_and_refugees_in_the_ceas_-_december_2016.pdf (accessed June 12, 2021)

126 Hedlund D, Wimark T. Unaccompanied children claiming asylum on the basis of sexual orientation and gender identity. J Refug Stud 2019; 32: 257-77.

127 Papademetriou T. European Union: status of unaccompanied children arriving at the EU borders. The Law Library of Congress. 2014. https://www.loc.gov/law/help/unaccompanied-children/ eu.php (accessed June 12, 2021).

128 Silva DS, Smith MJ. Limiting rights and freedoms in the context of 


\section{TLChild0339}

\section{Review}

Ebola and other public health emergencies: how the principle of reciprocity can enrich the application of the Siracusa Principles. Health Hum Rights 2015; 17: e52-57.

129 International Organization for Migration, UNICEF, UN High

Commissioner for Refugees. Access to education for refugee and migrant children in Europe. September, 2019. https://www.unhcr. org/neu/wp-content/uploads/sites/15/2019/09/Access-to-educationeurope-19.pdf (accessed June 12, 2021).

130 Jud A, Pfeiffer E, Jarczok M. Epidemiology of violence agains children in migration: a systematic literature review. Child Abuse Negl 2020; 108: 104634.

131 Wickramage K, Annunziata G. Advancing health in migration governance, and migration in health governance. Lancet 2018; 392: 2528-30.

132 The Alliance for Child Protection in Humanitarian Action. Field handbook for working with unaccompanied and separated children. 2017. https://alliancecpha.org/en/system/tdf/library/attachments / handbook-web-2017-0322.pdf?file=1\&type=node\&id=31236 (accessed June 12, 2021).

133 International Committee of the Red Cross. Inter-agency guiding principles on unaccompanied and separated children. Geneva: International Committee of the Red Cross, 2014

134 European Asylum Support Office. Practical guide on age assessment. March 7, 2018. https://www.easo.europa.eu/sites/ default/files/easo-practical-guide-on-age-assesment-v3-2018.pdf (accessed June 12, 2021).

Association of Directors of Children's Services. Age assessment guidance. October, 2015. https://adcs.org.uk/assets/documentation/ age_assessment_guidance_2015_final.pdf (accessed June 12, 2021).

136 Digidiki V, Bhabha J. Leaving and returning "home": the elusive quest for belonging and adulthood among african adolescents on the move. Kult Eduk 2019; 124: 143-56.

137 Centre for Humdata. Predictive analytics. https://centre.humdata. org/predictive-analytics/ (accessed June 12, 2021).

138 Rushton S, Williams OD. Frames, paradigms and power: global health policy-making under neoliberalism. Glob Soc 2012; 26: $147-67$.

139 Bacchi C, Goodwin S. Making politics visible: the WPR approach. In: Bacchi C, Goodwin S, eds. Poststructural policy analysis. Berlin: 30 Springer, 2016: 13-26.

140 UN High Commissioner for Refugees. UNHCR Turkey operational update. July, 2020. https://www.unhcr.org/tr/wp-content/uploads/ sites/14/2020/08/unhcr-turkey-operational-update-july.pdf (accessed June 12, 2021).

141 van Liempt I, Alpes MJ, Hassan S, Tunaboylu S, Ulusoy O, Zoomers E. Evidence based assesment of migration deals: the case of the EU Turkey statement. Utrecht: Universiteit Utrecht, 2017.

142 Enria N, Gerwens S. Greek-Turkish border crisis: refugees are paying the price for the EU's failure to reform its asylum system. March 25, 2020. https://blogs.lse.ac.uk/europpblog/2020/03/25/ greek-turkish-border-crisis-refugees-are-paying-the-price-for-theeus-failure-to-reform-its-asylum-system/ (accessed June 12, 2021).

143 Okyay AS. Turkey's post-2011 approach to its Syrian border and its implications for domestic politics. Int Aff 2017; 93: 829-46.

144 Turkish Ministry of Interior. Turkey: Law no 6458 of 2013 on foreigners and international protection. Oct 29, 2016. https://www. refworld.org/docid/5167fbb20.html (accessed June 12, 2021).

145 Asylum Information Database. Guarantees for vulnerable groupsTurkey 2020. May 31, 2021. https://asylumineurope.org/reports/ country/turkey/content-temporary-protection/guaranteesvulnerable-groups/ (accessed June 12, 2021).

146 Turkish Ministry of Interior. 5395 Child Protection Law. July 15, 2005. http://www.lawsturkey.com/law/juvenile-protection-law-5395 (accessed June 12, 2021).

147 Frank A. Uganda and the refugee problem: challenges and opportunities. Afr J Pol Sci Int Relat 2019; 13: 62-72.

148 Ministry of Health Uganda. Health Sector integrated refugee response plan. Jan 31, 2019. https://www.health.go.ug/cause/health sector-integrated-refugee-response-plan/ (accessed June 12, 2021).

(C) 2021 Elsevier Ltd. All rights reserved. 